\title{
THE APPLICABILIITY OF MIRANDA TO THE POLICE BOOKING PROCESS
}

After a criminal suspect has been arrested and taken to a police station or other law enforcement office, he is usually ${ }^{1}$ subjected to the process known as "booking," during which a record is made of his name, address, other identifying data, and the details of his arrest. ${ }^{2}$ The information obtained during booking is intended primarily for administrative use, ${ }^{3}$ and the questions are rarely objectionable from the suspect's point of view. In a small number of cases, however, the information requested during booking has later been used at trial as evidence against the suspect. ${ }^{4}$ The fact that booking occasionally does elicit incriminat-

1. After a suspect has been arrested, further questioning and investigation may reveal that in fact no crime was committed, that there is iusufficient evidence to prosecute him, or that prosecution is undesirable for some other reason. In such cases the individual may, in some jurisdictions, be released without being booked. Y. Kamisar, W. LaFave \& J. Israel, Modern Criminal Procedure 7 (4th ed. 1974).

2. The details of the booking process may vary from one jurisdictiou to the next. However, the procedures used in Durham, North Caroliua, as described below, are typical of the practices followed in most jurisdictions. See id. at 6-7; W. LAFAve, ARREST: THE DECISION to TAKE A SUSPECT INTO CUSTODY 379-82 (1965).

After a suspect has been arrested in Durham, identifying information is entered on a standard form (the North Carolina Internal Records Arrest Report) for permanent police files. The information required includes the suspect's complete name, alias or nickuame, complete address, place of birth, date of birth, age, sex, race, height, weight, hair, eyes, complexion, marital status, social security number, occupation, and the name and address of the suspect's employer or school. See Wainwright v. City of New Orleans, 392 U.S. 598, 605-06 (1968) (Warren, C.J., dissenting from dismissal of writ of certiorari); E. Williams, Modern Law Enforcement and Police Science 57 (1967) (sample arrest report form from an Illinois city). In certain statutorily defined cases, the suspect may also be fingerprinted and photographed. See, e.g., N.C. GEN. STAT. § 15A-502 (1975). See also Modern Criminal Procedure, supra note 1, at 7 . If the suspect is to be jailed, all of his personal possessions will be taken, inventoried, and stored. See N. Pomrenke, Law ENforcement Manual: Rules and Regulations $\$$ 710.1 (1967) (pamphlet published by the Institute of Government, University of North Carolina at Chapel Hill). See also F. Remington, D. Newman, E. Kimball, M. Meldi \& H. Goldstein, Criminal Justice Administration 367 (1969).

3. See notes $46-52$ infra aud accompanying text.

4. See, e.g., United States ex rel. Hines v. LaVallee, 521 F.2d 1109 (2d Cir. 1975), cert. denied, 423 U.S. 1090 (1976) (statements about marital status and number of children used as incriminating evidence); United States v. La Monica, 472 F.2d 580 (9th Cir. 1972) (use of defendant's explanation of receipt during routine inventory of his personal possessions); Farley v. United States, 381 F.2d 357 (5th Cir.), cert. denied, 389 U.S. 942 (1967) (use of suspect's address); People v. Hernandez, 263 Cal. App. 2d 242, 25354, 69 Cal. Rptr. 448, 454-55 (1968) (use of suspect's birthdate); People v. Walters, 252 
ing evidence raises a difficult question: must the information obtained from the suspect during booking be excluded from evidence at a subsequent trial if the suspect was not warned before booking of his constitutional rights to remain silent and to have counsel present? ${ }^{5}$ In other words, are the procedural requirements of Miranda $v$. Arizon $a^{6}$ applicable to the booking process?

Cal. App. 2d 336, 338-39, 60 Cal. Rptr. 374, 376 (1967) (use of suspect's place of employment and wife's address); State v. Rasmussen, 92 Idaho 731, 735-36, 449 P.2d 837, 841-42 (1969) (use of suspect's statement as to occupation); Clarke v. State, $3 \mathrm{Md}$. App. 447, 450-52, 240 A.2d 291, 293-94 (1968) (use of suspect's statement as to his place of employment in order to find stolen goods); State v. Jordan, 506 S.W.2d 74, 8283 (Mo. Ct. App. 1974) (use of suspect's social security number as incriminating evidence).

5. "No person . . . shall be compelled in any criminal case to be a witness against himself." U.S. CoNST. amend. V.

"In all criminal prosecutions, the accused shall enjoy the right . . . to have the Assistance of Counsel for his defense." U.S. CoNST. amend. VI.

6. 384 U.S. 436 (1966). In Miranda, the Supreme Court acknowledged the difficulty of determining on a case-by-case basis whether incriminating statements elicited from an individual who is in police custody are the product of that individual's exercise of free will. Id. at 445-48. Accordingly, the Court established procedural rules designed to protect the suspect from the coinpelling influences inherent in custodial interrogation. Id. at 444 . The police must warn a suspect in custody that he has the right to remain silent, that anything he says may be used as evidence against him, that he has the right to the presence of an attorney, and that if he cannot afford an attorney, one will be provided for him. Id. The suspect must waive these rights before any interrogation can take place. Id. at 444-45. Unless these procedures are complied with, any admissions resulting from custodial interrogation are presumed to be the product of coercion and are therefore inadmissible. Id. at 444, 498-99.

Recent cases have cast doubt on the continued vitality of the Miranda doctriue and the exclusionary rule, the means by which its strictures are enforced. In Harris v. New York, 401 U.S. 222 (1971), the Supreme Court neld that statements elicited from a defendant in violation of Miranda could be used for impeachment purposes. In Michigan v. Tucker, 417 U.S. 433 (1974), where the custodial interrogation occurred before the Miranda decision, but was nonetheless subject to the Miranda rules because the defendant's trial was delayed until after Miranda, the Court refused to apply the Miranda exclusionary rule, noting that there had been no willful misconduct by the police. Cf. United States v. Peltier, 422 U.S. 531 (1975) (Court refused to give retroactive effect to a relatively new search and seizure rule which would have deprived the government of evidence in a case where there had been no intentional governmental misconduct); Michigan v. Mosley, 423 U.S. 96 (1975) (holding that admissibility of inculpatory statements, made while suspect is in custody and after he has elected to remain silent, depends on whether police "scrupulously honor" his right to cut off questioning at any time). The analyses in Tucker, Peltier, and Mosley differ markedly from the analysis in Miranda, which focused not only on the presence of imtentional police misconduct, but also on subjective impressions of the defendant. See Miranda v. Arizona, 384 U.S. at $468-69$.

Even if the Miranda rules are replaced by a less stringent scheme of procedural safeguards, the status of booking in relation to other stages of the criminal investigation process will remain an important question. Regardless of what procedures are substitut- 
Although booking occurs after a suspect has been taken into custody, there has been disagreement among the federal circuits on whether Miranda should apply to this early stage of the criminal process. The Court of Appeals for the District of Columbia Circuit has held that an admission obtained during booking must be excluded from evidence unless the Miranda procedures are strictly followed, ${ }^{7}$ while the Courts of Appeals for the Second, ${ }^{8}$ Fifth, ${ }^{9}$ Eighth, ${ }^{10}$ and Ninth $^{11}$ Circuits have held Miranda to be mapplicable to booking. ${ }^{12}$ The purpose of this Note

ed for those mandated by Miranda, it will be necessary to determine their applicability in the borderline custodial context of booking.

7. Proctor v. United States, 404 F.2d 819 (D.C. Cir. 1968) (suspect's answer to arresting officer's question whether he was employed held not admissible since warnings had not been given before questioning). See notes 20-24 infra and accompanying text.

8. United States ex rel. Hines v. LaVallee, 521 F.2d 1109 (2d Cir. 1975), cert. denied, 423 U.S. 1090 (1976) (suspect's answers about marital status and number of children held admissible although warnings were not given before booking). See notes 34-43 infra and accompanying text.

9. Farley v. United States, 381 F.2d 942 (5th Cir.), cert. denied, 389 U.S. 942 (1967) (suspect's answer as to where he lived held admissible even though he had previously indicated that he did not want to be questioned). See notes 13-19 infra and accompanying text.

10. Morrison v. United States, 491 F.2d 344 (8th Cir. 1974) (suspect's criminal record held admissible although the information was obtained from him after he had refused to waive his Miranda rights). See notes 29-33 infra and accompanying text.

11. United States v. La Monica, 472 F.2d 580 (9th Cir. 1972) (admission obtained during inventory of suspect's personal possessions held admissible even though suspect had refused to discuss his case in the absence of his attorney). See notes 25-28 infra and accompanying text.

12. While the Courts of Appeals for the Second, Fifth, Eighth, and Ninth Circuits have all been willing to make exceptions to Miranda for booking information in particular cases, their positions on the general issue of the applicability of Miranda to all booking information may not be identical. The decision of the Court of Appeals for the Fifth Circuit in Farley v. United States, 381 F.2d 357 (5th Cir.), cert. denied, 389 U.S. 942 (1967), was apparently restricted to the facts of that case, and it is uncertain whether the circuit will adopt a general rule applicable to all booking situations. See United States v. Martinez, 512 F.2d 830 (5th Cir. 1975) (court declined to decide whether arrested subject must be given Miranda warnings before being asked to state his nationality); United States v. Menichino, 497 F.2d 935, 939-41 (5th Cir. 1974) (dicta: better view among conflicting authorities is that Miranda is mapplicable to booking). The Eighth Circuit's analysis in Morrison v. United States, 491 F.2d 344 (8th Cir. 1974), would be applicable to any case where the identifying information obtained is a matter of public record (such as a name, address, or criminal record), but in a case involving a matter which cannot be found in public records (such as an alias) the court might well hold that Miranda is applicable. The Ninth Circuit's decision, United States v. La Monica, 472 F.2d 580, 581 (9th Cir. 1972), is worded only in terms of the facts of that particular case, but since the facts emphasized (no investigative purpose, no persistent or coercive interrogation, and no guile or trickery) would probably apply to most other booking cases, the case could be viewed as expressing a broad rule exempting the booking process from Miranda. Only in United States ex rel. Hines v. LaVallee, 521 F.2d 1109 (2d Cir. 1975), cert. denied, 423 U.S. 1090 (1976), is it clear that a general rule exempting booking from the scope of Miranda is being adopted. 
is to examine the reasoning used by these courts in reaching their respective conclusions and to study the ramifications of their positions. It will be shown that a strict application of Miranda to all booking questions would completely frustrate the maintenance of necessary police administrative records. It would be constitutionally impermissible, however, to exempt from the Miranda safeguards all questioning which might come under the booking rubric. Therefore, a compromise rule will be suggested, which will allow the compilation of vital police records without interfering with the suspect's privilege against selfincrimination.

\section{Judicial AtTitudes TOWARD THE EXCLUSION OF INCRIMINATORY Statements Made During the Booking Process}

The first federal appellate court to decide a case involving the applicability of Miranda to routine booking questions was the Court of Appeals for the Fifth Circuit, in Farley v. United States. ${ }^{13}$ Farley was arrested after being found near the scene of an attempted burglary at 2:30 a.m. During a subsequent interview with a law enforcement officer, Farley refused to discuss his case and referred the officer to his attorney who was not then present. After this refusal to talk, the officer asked, "Will you tell me where you live?", and Farley stated his address. ${ }^{14}$ At trial the prosecution used the address to show that Farley lived a considerable distance from the scene of the crine and had no good reason to be there at 2:30 a.m. ${ }^{15}$ Farley was convicted and appealed, urging that his address had been obtained in violation of Miranda and was therefore inadmissible at trial.

The court of appeals pointed out that where Farley lived was a matter of public knowledge, and that the authorities no doubt would have obtained his address very quickly by independent investigation if he had refused to give it to them. ${ }^{16}$ It also noted that the address had very little probative value with regard to Farley's guilt or innocence. ${ }^{17}$ Furthermore, there was no evidence that the officer had in any way

13. 381 F.2d 357 (5th Cir.), cert. denied, 389 U.S. 942 (1967).

14. Id. at 358-59. It is not clear that the officer who asked Farley where he lived was doing so for booking purposes. He may have been trying to obtain an investigative lead or perhaps merely to start a conversation. In any case, the question is one which is regularly asked during booking, see note 2 supra, and the Farley court's analysis is applicable to the Miranda-booking issue.

15. 381 F.2d at 358 .

16. Id. at 359 .

17. Id. 
attempted to compel the defendant to answer the question. ${ }^{18}$ Under such circumstances, the court found that it would not be "reasonable to apply Miranda so strictly as to exclude the response to that inquiry."18

A year later, in Proctor v. United States, ${ }^{20}$ the Court of Appeals for the District of Columbia Circuit ruled that Miranda should be strictly applied to booking. Proctor, who was charged with robbery, testified at trial that he had been at work at the time of the robbery. In order to disprove Proctor's alibi defense, the prosecution called on the officer who had booked Proctor, and he testified that Proctor had told him that he had been unemployed at the time of the robbery. ${ }^{21}$ Proctor appealed from his conviction on the ground that his statement to the booking officer was inadmissible. ${ }^{22}$

The Proctor court did not mention Farley, nor did it make reference to the Farley criterion of whether the information obtained was a matter of public knowledge. Rather, the court identified the presence of coercion in the booking process as the critical factor. The booking officer's intent was found to be irrelevant. Even if no coercion had been intended, the suspect's answer could not be accepted as voluntary because of the inherent coerciveness of the situation. ${ }^{23}$ The case was remanded for determination of whether the suspect had executed a valid waiver of his Miranda rights before responding to the booking questions. ${ }^{24}$

In United States v. La Monica, ${ }^{25}$ the Ninth Circuit jomed the Fifth Circuit by adinitting into evidence a statement elicited during routine post-arrest police procedures. After La Monica was arrested for transporting marijuana into the United States, he was informed of his Miranda rights and stated that he did not want to discuss his case. While compiling an inventory of La Monica's personal effects, however, a customs agent came across a receipt for attorney's fees and asked him what it was. La Momica replied that he had paid an attorney five

18. Id. Apparently, the court was referring here to overt acts of coinpulsion rather than to any compulsion inherent in custodial interrogation.

19. Id.

20. 404 F.2d 819 (D.C. Cir. 1968).

21. Id. at 820 .

22. Proctor was decided before Harris v. New York, 401 U.S. 222 (1971), where the Supreme Court held that a statement obtained in violation of Miranda's procedural rules is admissible for the purpose of impeaching a defendant's testimony. Under Harris, the statement made to the booking officer would clearly be admissible, if used merely to impeach Proctor and not as substantive proof of his guilt.

23. $404 \mathrm{~F} .2 \mathrm{~d}$ at $820-21$.

24. Id. at 822 .

25. 472 F.2d 580 (9th Cir. 1972). 
hundred dollars before going to Mexico, "just in case anything went wrong on the trip."28 Without reference to either of the two previous cases in which the issiue had been considered, the Ninth Circuit affirmed La Monica's conviction on the basis of the agent's non-investigative intent in asking about the receipt, a factor which had been found irrelevant in Proctor. ${ }^{27}$ The court focused on the fact that the agent had not been trying to elicit incriminating information, but merely atteinpting to identify the defendant's personal possessions. ${ }^{28}$

In Morrison v. United States, ${ }^{28}$ the defendant was arrested for passing counterfeit money. He was informed of his rights and refused to talk about the incident leadimg to his arrest. During "processing" by Secret Service agents, however, he did give general background information, including his prior criminal record and the fact that he was "presently on parole from a federal counterfeit conviction. . . ."30 This conviction was admitted at trial for the purpose of proving Morrison's intent to defraud. . $^{31}$

On appeal, the Eighth Circuit rejected Morrison's claim that the admission of his prior conviction violated his rights under Miranda. While the court did not mention Farley, Proctor or La Monica, it relied on the Farley-type argument ${ }^{32}$ that Miranda does not protect a defendant from being compelled to disclose matters of public knowledge. The Secret Service agents therefore were not required to obtain a waiver of rights from Morrison before questioning him about his criminal record. ${ }^{33}$

The inost recent, and best reasoned, opinion on the applicability of Miranda to booking questions is that of the Court of Appeals for the Second Circuit in United States ex rel. Hines v. LaVallee. ${ }^{34}$ In that case, a rapist had told his viction that he had been inarried eleven years and had two children. Hines was later arrested because he matched the victim's description of her assailant. Without having given the Miranda warnings, the arresting officer questioned Hines about his background and learned that he had been married eleven years and had two chil-

26. Id. at 581 .

27. See text accompanying note 23 supra.

28. 472 F.2d at 581.

29. 491 F.2d 344 (8th Cir. 1974).

30. Id. at 345 .

31. Id. See note 47 infra.

32. See text accompanying note 16 supra.

33. Id. at 346-47. The court not only found Miranda inapplicable, but also implied that this information was wholly outside of the fifth amendment's protections. Id. at 347.

34. 521 F.2d 1109 (2d Cir. 1975), cert. denied, 423 U.S. 1090 (1976). 
dren. ${ }^{36}$ After being convicted in state court, ${ }^{36}$ Hines applied to the federal district court for a writ of liabeas corpus, arguing that the arresting officer's testimony about the booking information should have been ruled inadmissible as obtained in violation of his rights under Miranda. The district court recognized the existence of a conflict among the circuits and followed Farley, holding the evidence properly admitted and denying the writ. ${ }^{37}$

In affirming the district court's decision, the Second Circuit interpreted Miranda as applicable only to "questioning designed to investigate crimes or the involvement of the arrested person or others in crimes' as distinguished from 'non-investigative questioning.' "38 Since the questions asked about Hines' marital status were needed for booking and were not asked for investigative purposes, the court held them to be outside the scope of the Miranda safeguards and concluded that the information obtained had been properly admitted into evidence. ${ }^{30}$

The significance of the case, however, lies not so much in the relatively straight-forward result as in the court's general discussion of the uncertain status of identification data under the fifth amendment. The court first acknowledged the inherent tension between the administrative need for immediate ascertaininent of a suspect's identity and the possibility that superficially innocuous data "may in a particular context provide the missing link required to convict." ${ }^{30}$ It then pointed out that even if a suspect refused to identify himself, a court could compel him to furnish physical evidence which would enable the police to determine his identity, regardless of the potential incrimmatory effect of such evidence. ${ }^{41}$ The court found that

[a]lthough data thus obtained may be distinguished from information as to identity furnished orally on the ground that the latter is testimonial in character, the line of demarcation is thin. ${ }^{42}$

35. Id. at 1110. This conversation took place enroute to the police station, and the officer's questions were, in the court's words, "designed to pass the time by seeking background data." Id. In its discussion of the issues of the case, however, the court treated the defendant's statement as one obtained during booking.

36. People v. Hines, New York Supreme Court, County of the Bronx, Dec. 18, 1972 (unreported), affd per curiam, 43 App. Div. 2d 769, 350 N.Y.S.2d 145 (1st Dep't 1973).

37. The Second Circuit likewise acknowledged the split of authority while discussing the unreported district court opinion. 521 F.2d at 1111.

38. Id. at 1113, quoting Model Code of Pre-Arraignment Procedure $§ 140.8(5)$

(Tent. Draft No. 6, 1974).

39. Id. at 1113 .

40. Id. at 1112 .

41. See notes 56-64 infra and accompanying text.

42. $521 \mathrm{~F} .2 \mathrm{~d}$ at 1112 . 
The essential question was posed by implication: if an mdividual can be compelled, consistent with his constitutional rights, to produce evidence which will lead to the certain discovery of his identity by the police, and which may ultimately incriminate him, then why can lie not simply be compelled to reveal his identity orally? ${ }^{43}$

\section{The ApPlicability of the Fifth AMENDMENT TO BOOKING}

In expanding its discussion beyond the limited issue of the applicability of Miranda to the booking process, the Hines opimon raises the more fundamental question of whether a suspect being booked enjoys any fifth amendment protection against self-incrimination. ${ }^{44}$ From a theoretical standpoint, neither the police need for administrative information nor the practical similarities between compelling nontestimonial evidence of identity and requiring an oral statement of identity (the factors cited by the Hines court) individually warrant forcing a suspect to incriminate himself during booking. The combined weight of these two considerations, however, may justify the view that some minimal identifying information is not within the scope of the fifth amendment privilege.

\section{The Need for Administrative Information}

If the information requested during booking were used primarily to aid the police in their investigation of crime, then booking would be indistinguishable from other forms of custodial interrogation, and any exception to either Miranda or the fifth amendment would be unjustifia-

43. See text accompanying note 65 infra. The Hines court held alternatively that even if the booking information was not admissible under Miranda, its admission would have been harmless error because of the overwhelming independent evidence of Hines' guilt. 521 F.2d at 1113. See Harrington v. California, 395 U.S. 250 (1969); Chapman v. California, 386 U.S. 18 (1967). While the harmless error doctrine was applicable in the particular fact situation in Hines, it cannot, standing alone, justify the Hines holding that Miranda is inapplicable to booking. There is no guarantee that in every case where an individual's response to a booking question is admitted at trial over his objection the admission will be harmless. If the Hines rule is to be extended to all cases involving a response to a booking question, the rule must be one which can stand on its own merits no matter how harmful the admitted statement is to the defendant's case. If, on the other hand, the Hines "rule" is usable only in cases where the harmless error doctrine itself could be relied upon, then it is superfluous.

44. Even if Miranda were not applicable to booking, self-incrimination problems could still arise if the fifth amendment privilege were applicable. A well-informed individual might refuse to answer a particular booking question on the ground that his answer would be incriminatory. 
ble. ${ }^{45}$ However, this information is needed for administrative purposes which normally have nothing to do with proving the individual's guilt or innocence. The police officers who have arrested a suspect need to know if he is wanted elsewhere so that other police agencies searching for the same person can be notified. ${ }^{40}$ The individual's identity will also be needed to obtain a record of any previous arrests and convictions. This record may, of course, have some evidentiary value, ${ }^{47}$ but it also may be needed to decide upon security ${ }^{48}$ or health ${ }^{49}$ measures during the suspect's incarceration, and will certainly be needed when he is brought before a nagistrate to fix bail. ${ }^{50}$ Finally, the booking process serves as a check on the police since it requires the maintenance of a record of those arrested and the charges against thein. ${ }^{51}$ This record may be helpful in preventing such abuses of the arrest power as the harassment of particular individuals or groups. ${ }^{52}$ Thus, there are important admin-

45. Of course, an individual could be compelled to provide incriminating booking information if he were granted "use immunity," thus preventing the government from using the information as evidence or as a lead to evidence against the individual. See Kastigar v. United States, 406 U.S. 441 (1972); Murphy v. Waterfront Comm'n, 378 U.S. 52, 79 n.18 (1964). Such a restriction would be unacceptable to the police in most cases, however, since it is virtually impossible to investigate a crime without using data about the suspect's identity and background in some manner.

46. See The President's Commission on Law Enforcement and administration op Justice, Task Force Report: The Police 57 (1967). See also A Master Plan for Criminal JUstice Information Systems for the State of North Carolina (prepared for the Governor's Committee on Law and Order) 3-3.

47. A record of prior convictions may be used as evidence for "proof of motive, opportunity, intent, preparation, plan, knowledge, identity, or absence of mistake or accident." FED. R. Ev. 404(b); see C. MCCORMICK, HANDBOOK of THE LAW of EVIDENCE $\$ 190$ (2d ed. 1972). See note 31 supra. It may also be used to impeach the defendant if he testifies. See id. $\S 43$; Fed. R. Ev. $\S 609$ (a).

48. An individual who had a previous record of escapes or of violence might be jailed in a maximum security cell or unit, and separated from other, less dangerous prisoners. See A Master Plan for Criminal Justice INFormation Systems for the State of North Carolina, supra note 46, at 3-3, 3-9.

49. See id. Special health neasures might be required if the suspect had a history of drug dependence, mental disturbances, or some physical weakness such as a heart condition.

50. See, e.g., United States ex rel. Hines v. LaVallee, 521 F.2d 1109, 1112 (2d Cir. 1975), cert. denied, 423 U.S. 1090 (1976); 18 U.S.C. \$ 3146(b) (1970) (previous convictions included in a list of factors to be considered in setting bail).

51. See State v. Smith, 295 Minn. 65, 69, 203 N.W.2d 348, 351 (1972); State v. Jordan, 506 S.W.2d 74, 83 (Mo. Ct. App. 1974); ProjeCT on LAW ENFORCEMENT Policy and Rulemaking, Model Rules, Release of ARrest and Conviction Records Rule 101 (approved draft 1974) (published by the College of Law of Arizona State University and the Police Foundation).

52. "'Booking' is an administrative record of an arrest .... [T]his official and permanent arrest record 'provides a valuable protection against secret arrests and improper police tactics.' "Wainwright v. City of New Orleans, 392 U.S. 598, 605-06 
istrative benefits to be derived from booking which are completely divorced from any tendency of that process to elicit incriminating evidence from a suspect.

While the Hines court relied in part on the administrative value of booking to justify exempting the process from Miranda procedures, ${ }^{\mathrm{G3}}$ it failed to consider how much data is really necessary to meet the administrative need for an arrested person's identity. Although all of the information requested during booking may be desirable from the police viewpoint, ${ }^{54}$ it is not all needed for administrative (as opposed to investigative) reasons. There is no administrative reason, for example, why a suspect should have to give explanations about the items in his possession at the time of his arrest, or disclose his marital status, the number of his children, his place of employment, or his prior criminal record. ${ }^{55}$ Thus, while the need for administrative information lends support to the argument that an arrested suspect should be required to give the police some identifying data, it does not.justify requiring him to answer a broad range of booking questions, some of which serve no administrative purpose and could only be intended to establish leads for police investigation. The arrested suspect should be sufficiently "identified" for administrative purposes when he has disclosed his name and address.

\section{Comparison of Identification Data to Nontestimonial Evidence}

The fifth amendment prohibition applies only to the compulsion of testimonial evidence. ${ }^{56}$ In distinguishing between testimonial and nontestimonial evidence the courts have generally relied upon a cominunicative test, asking whether the evidence consists of or was produced by a communication of the defendant's thoughts. ${ }^{57}$ Thus, a written or verbal

(1968) (Warren, C.J., dissenting from dismissal of writ of certiorari), quoting, LA. CoDE CrIM. PRo. ANN. art. 228, Official Revision Comment (a) (West 1967). See also W. LAFAVE, supra note 2, at 379-82.

53. 521 F.2d at 1112; see note 39 supra and accompanying text.

54. In F. Inbau \& J. Reid, Criminal INTERrogation and Confessions 13-14 (2d ed. 1967), for example, it is suggested that before an interrogator ineets with a suspect, he should familiarize himself with all of the facts of the case and with the suspect's personal background. This study would no doubt include an examination of the arrest report. See also A Master Plan for Criminal Justice Information Systems for the State of North Carolina, supra note 46, at 3-3, which suggests that information on the suspect's background may provide investigative leads.

55. Each of these items of information may have an incriminatory effect. See note 4 supra and accompanying text.

56. See, e.g., Schmerber v. California, 384 U.S. 757, 764 (1966).

57. See United States v. Dionisio, 410 U.S. 1, 6, 7 (1973); Gilbert v. California, 388 
statement would be testimonial evidence, but a handwriting or voice exemplar examined solely for its physical characteristics and not for any communicative content would be nontestimonial, ${ }^{58}$ and therefore outside the protection of the fifth amendment privilege, even if it were clearly incriminating. Under this communicative test, it has been held that a defendant may be compelled to furnish fimgerprints ${ }^{59}$ or blood samples, ${ }^{60}$ to participate in a line-up ${ }^{61}$ or submit to photographing, ${ }^{62}$ and to provide handwriting ${ }^{63}$ and voice exemplars, ${ }^{64}$ simce all of these procedures produce only nontestimonial evidence.

U.S. 263, 266-67 (1967); Schmerber v. California, 384 U.S. 757, 764 (1966). Perhaps the best statement of the communicative test is that made by Justice Holmes in Holt $v$. United States:

[T]he prohibition of compelling a man in a criminal court to be witness against himself is a prohibition of the use of physical or moral compulsion to extort communications from him, not an exclusion of his body as evidence when it may be material. 218 U.S. 245, 252-53 (1910).

58. See Gilbert v. California, 388 U.S. 263 (1967); ABA PROJECT ON STANDARDS for Criminal Justice, Standards Relating to Discovery and Procedure Before Trial § 3.1(a) (1970); Model Code of Pre-Arraignment Procedure $\S$ 160.2(3), $160.2(6)(1975)$.

59. See United States v. Wade, 388 U.S. 218, 223 (1967); Schmerber v. California, 384 U.S. 757, 764 (1966); Snow v. Oklahoma, 489 F.2d 278 (10th Cir. 1973); Ward v. United States, 486 F.2d 305 (5th Cir. 1973), cert. denied, 416 U.S. 990 (1974); United States v. Sanders, 477 F.2d 112 (5th Cir.), cert. denied, 414 U.S. 870 (1973); United States v. Cary, 470 F.2d 469 (D.C. Cir. 1972); Hackworth v. Beto, 434 F.2d 852 (5th Cir. 1970); Cornell v. Maryland, 396 F. Supp. 1092 (D. Md. 1975); Bonaparte v. Smith, 362 F. Supp. 1315, 1318-19 (S.D. Ga.), aff'd, 484 F.2d 956 (5th Cir. 1973), cert. denied, 415 U.S. 981 (1974).

60. See Schmerber v. California, 384 U.S. 757, 761 (1966); Ferguson v. Cardwell, 392 F. Supp. 750 (D. Ariz. 1975).

61. See United States v. Wade, 388 U.S. 218, 221-22 (1967); United States v. Jackson, 509 F.2d 499 (D.C. Cir. 1974); United States ex rel. Pierce v. Cannon, 508 F.2d 197 (7th Cir. 1974), cert. denied, 423 U.S. 841 (1975); United States v. Wilcox, 507 F.2d 364 (4th Cir. 1974), cert. denied, 420 U.S. 979 (1975); Reynolds v. Lockhart, 470 F.2d 161 (8th Cir. 1972).

62. See Simmons v. United States, 390 U.S. 377, 384 (1968); United States v. Jewett, 520 F.2d 581 (1st Cir. 1975); Nassar v. Vinzant, 519 F.2d 798 (1st Cir.), cert. denied, 96 S. Ct. 202 (1975); United States v. Hurt, 476 F.2d 1164 (D.C. Cir. 1973); Gilbert v. United States, 366 F.2d 923, $932-33$ (9th Cir. 1966), cert. denied, 388 U.S. 922 (1967).

63. See Gilbert v. California, 388 U.S. 263 (1967); United States v. Snider, 499 F.2d 424 (5th Cir. 1974), cert. denied, 419 U.S. 1115 (1975); United States v. Lincoln, 494 F.2d 833 (9th Cir. 1974); United States v. Hopkins, 486 F.2d 360 (9th Cir. 1973); United States v. Osborne, 482 F.2d 1354 (8th Cir. 1973); United States v. Brown, 398 F. Supp. 444 (E.D. Mich. 1975).

64. See United States v. Dionisio, 410 U.S. 1 (1973); United States v. Baller, 519 F.2d 463 (4th Cir.), cert. denied, 423 U.S. 1019 (1975); United States v. Franks, 511 F.2d 25 (6th Cir.), cert. denied, 422 U.S. 1042 (1975); United States v. Bozeman, 495 F.2d 508 (5th Cir. 1974), cert. denied, 422 U.S. 1044 (1975); United States v. Ryan, 478 F.2d 1008 (5th Cir. 1973). 
As noted above, the Hines opinion raises a troublesome question about the validity of this traditional cominunicative test for distinguishing between testimonial and nontestimonial evidence: if an individual may be compelled to submit to fingerprinting, participate in a line-up, or provide handwriting and voice exemplars, where is the logic in allowing him to refuse to state his identity? ${ }^{65}$

Although the courts have usually rehed on the communicative test, ${ }^{66}$ there is a limited Supreme Court precedent for departure from it which suggests a solution to the dilemma posed in Hines. In California v. Byers, ${ }^{67}$ the Court upheld the constitutionality of a California statute which required the driver of any motor vehicle involved in an accident to stop and give his name and address. ${ }^{88}$ Byers, who was prosecuted for failure to comply with the statute, contended that giving his name and address would tend to incriminate him and that the statute was therefore inconsistent with the fifth amendment. Rejecting Byers' claim, a plurality of the Court found that the California statute was enacted for a valid regulatory purpose, ${ }^{69}$ and that compliance with the law posed no untoward risk of self-incrimination, ${ }^{70}$ rendering the reporting requirement not "incriminating in the traditional sense."

65. See 521 F.2d at 1112; notes 34-44 supra and accompanying text.

66. See cases cited in note 57 supra.

67. 402 U.S. 424 (1971).

68. CAL. Vehicle Code $\$ 20002$ (a) (1) (West 1971).

69. 402 U.S. at 430 . The plurality opinion was concurred in by four of the Justices. Justice Harlan, concurring only in the result, maintained that Byers' name and address were both incriminating and testimonial evidence, but found that Byers could be compelled to disclose them anyway, under a balancing approach which took into account the governmental need for the information, the nature of the information, and the fact that there was no other way to obtain it. Id. at 434 et seq.

70. Id. at 431 .

71. Id. Another rationale advanced for the decision in Byers was that the appellant's name and address were not incriminating. At least one federal court of appeals, relying on Byers, has concluded that "[t]he identification of oneself is not selfincriminating and thus not protected by the Fifth Amendment." United States v. Leal, 460 F.2d 385, 389 (9th Cir.), cert. denied, 409 U.S. 889 (1972); cf. United States v. Leyba, 504 F.2d 441, 443 (10th Cir. 1974), cert. denied, 420 U.S. 934 (1975). This broad conclusion is not warranted; whether an item of evidence is incriminating depends entirely on the circumstances of the particular case. A holding that a name and address are not inculpatory in civil cases would not necessarily mean that they are not incriminating in criminal cases, and a holding that they are not incriminating in one criminal case would not necessarily mean that they are not in another criminal case:

The government argues that in no case can it be incriminating to ask a person his name. This seems dubious. "Are you John Wilkes Booth?" might well have been a dangerous question if a policeman had been there to ask it when the notorious assassin of President Lincoln stumbled into Dr. Mudd's office for treatment of his injured leg. United States v. Bey, 385 F. Supp. 227, 229 (W.D. Pa. 1974), vacated and remanded, 517 F.2d 1399 (3d Cir. 1975).

When the divulgence of a name injures the suspect only in the sense that it identifies 
plurality went on to uphold the statute on an alternative ground which opened the door to a simple if somewhat arbitrary resolution of the Hines dilemma-that disclosure of a name and address was not "testimonial" in nature, and hence not protected by the fifth amendment. ${ }^{72}$

In reaching its decision in Byers, the plurality made repeated reference to the automobile accident context in which the California statute was to be apphed; ${ }^{73}$ at the outset, Chief Justice Burger noted that the case presented a "narrow" question. ${ }^{74}$ Nonetheless, several lower federal courts have relied on Byers for the proposition that an individual may always be compelled to divulge his name and address. ${ }^{75}$

him as a person whom the police have been seeking in connection with a crime, then it should not be constitutionally protected even though it is, in a sense, incriminating. Assume, for example, that a man named James Moriarty is wanted by the police for robbery, and that they find and arrest him through the use of a detailed description. If the suspect refuses to identify himself because that would prove beyond any doubt that he is the person who was being sought, then it would seen, intuitively, that he should not be entitled to invoke the fifth amendment's protection: the name James Moriarty does not prove or disprove his guilt in the crime for which he was wanted, but inerely makes it possible to initiate prosecution and prove his guilt through other evidence.

Cases can arise, however, where a suspect's name would be an item of substantive evidence tending to prove his guilt. For example, in United States v. Bey, $385 \mathrm{~F}$. Supp. 227 (W.D. Pa. 1974), vacated and remanded, 517 F.2d 1399 (3d Cir. 1975), government agents were informed that a gun had been shipped from Denver to one Tarik Ali Bey in Pittsburgh. The agents went to the defendant's home, and without giving the Miranda warnings, asked him if he was Tarik Ali Bey. He said he was, and the agents then asked him if he had been previously convicted of a felony under the name of Warren Williams. (Neither name was an alias. Williams was his "legitimate family name," 385 F. Supp. at 228 n.1, and Bey was his chosen Muslim name.) Bey answered affirmatively, and he was then charged with violating 18 U.S.C. $\$ 922(\mathrm{~h})$ (1970), which makes it a crime for any person who has been convicted of a felony "to receive any firearm . . . which has been shipped or itransported in interstate . . . commerce." The district court suppressed Bey's statements because the agents had failed "to give the appropriate warnings until after the evidence had been extracted." 385 F. Supp. at 229. The court, citing Byers, recognized that a name might not be "testimonial," id. at 229 \& n.4, but felt that "the agents had extracted from the defendant's own mouth evidence completely establishing his guilt. ...." Id. at 229.

Thus, Bey shows that while a name may be nontestimonial, see text accompanying note 72 infra, it clearly may be incriminatory in certain situations. An address can also be incriminating evidence. See, e.g., Farley v. United States, 381 F.2d 357 (5th Cir.), cert. denied, 389 U.S. 942 (1967). Thus, the Supreme Court's holding in Byers that Byers' name and address were not incriminating should be limited to the particular facts involved in the case, and should not be considered controlling in criminal cases involving an entirely different set of facts.

72. 402 U.S. at 431-34.

73. See id. at $430-31,433-34$.

74. Id. at 425 .

75. See, e.g., United States v. Camacho, 506 F.2d 594, 596 (9th Cir. 1974); United States v. Leyba, 504 F.2d 441, 443 (10th Cir. 1974), cert. denied, 420 U.S. 934 (1975); United States v. Leal, 460 F.2d 385 (9th Cir.), cert. denied, 409 U.S. 889 (1972). But 


\section{The Scope of the Privilege Against Self-Incrimination During Booking}

The import of the preceding discussion for the booking process is that the police slould be able to require any arrested suspect to state lis name and address. Insofar as these itens of information are nontestimonial, they are not protected by the fifth amendinent, even if clearly incriminating. ${ }^{70}$ If compelling a suspect to reveal his name and address does not offend the privilege against self-incrimination, then it cannot be held violative of the inore limited Mirand $a$ safeguards. ${ }^{77}$

There is no basis, however, for suggesting that any additional identifying information elicited during booking is exempt from the privilege against self-incrimination: communicative disclosures other than a suspect's name and address are clearly testimonial. ${ }^{78}$ More important-

see United States v. Bey, 385 F. Supp. 227, 229 (W.D. Pa. 1974), vacated and remanded, 517 F.2d 1399 (3d Cir. 1975).

In Byers, the Court acknowledged that it was balancing (1) the individual's privilege against self-incrimination and (2) the State's need for information to implement a regulatory, non-criminal scheme. 402 U.S. at 427 . See also United States v. San Juan, 405 F. Supp. 686, 694-95 (D. Vt. 1975) (holding constitutional the reporting requiremeuts of the Bank Secrecy Act, 31 U.S.C. $\$ 1101(a)$, (b) (1970)). It seems questionable, therefore, to extend the holding in Byers to situations where the governmental need for information is as closely related to the enforcement of crimmal laws as it is in booking. There are two considerations, however, which seem to justify such an extension. First, even though a suspect's name and address may be used as evidence against him, the primary reason for obtainiug such data after arrest is to help the police aud judicial officers make certain administrative decisions, which could not be made without that information. Second, the classification of an item of evidence as nontestimonial (unlike its classification as non-mcriminating, see note 71 supra) should not change from case to case. It is hard to imagine a case where a blood sample, or the physical characteristics of a voice, for example, could be testimonial evidence. Such items are never testimonial. Admittedly, an oral statement of one's name and address does not exactly match the other items of evidence which have been held nontestimonial-it is the only one which does not fit the communicative test. Nonetheless, it would seem illogical to say that a person's name and address are nontestimonial in one case and testimonial in another: the classification as nontestimonial should remain the same across the board. For these reasons, the Byers holding that a name and address are nontestimonial should be applicable not only to civil hit-and-run statutes such as the one involved in Byers, but also to criminal booking cases.

76. See, e.g., Farley v. United States, 381 F.2d 357 (5th Cir.), cert. denied, 389 U.S. 942 (1967); People v. Walters, 252 Cal. App. 2d 336, 60 Cal. Rptr. 374 (1967).

77. The purpose of the procedural rules of Miranda is to protect the privilege against self-imcrimination. Miranda v. Arizona, 384 U.S. 436, $442-44$ (1966). There would be no point, therefore, in extending the coverage of those rules beyond the scope of the privilege.

78. Indeed, in California v. Byers, the Supreme Court hinted that Byers could not constitutionally have been compelled to provide any information other than his name and address:

We are not called on to decide, but if the dictum of the Sullivan opinion were followed, the driver having stopped and identified himself, pursuant to the stat- 
ly, there is no need for such additional information except as evidence or leads to evidence showing the suspect's guilt. ${ }^{79}$ The fifth amendment privilege is intended to force the government to produce evidence against an individual "by its own independent labors, rather than by the cruel, simple expedient of compelling it from his own mouth."80 Once the police have a suspect's name and address, they should be able to find any other desired identifying data through their own investigation, ${ }^{81}$ and the suspect should not be compelled to help them do it. ${ }^{82}$

\section{The Applicability of Miranda to Booking}

The fact that a suspect has the right not to be compelled to disclose incriminating testimonial identification data does not necessarily mean that the booking procedures designed to obtain such data should be governed by the detailed prescriptions of Miranda. In attempting to show that the Miranda rules are not necessary during booking, the Farley, La Monica, Morrison, and Hines courts identified two major distinctions between questioning which accompanies booking and most other forms of custodial interrogation.

\section{The Lack of Investigative Intent}

An officer who is booking a suspect does not ordimarily do so with the intent of gathering incriminating evidence. This factor was heavily relied upon in La Monica and Hines, ${ }^{83}$ while the Proctor court found it

ute, could decline to make any further statement. 402 U.S. 424,434 n.6 (I971).

But cf. United States v. Leyba, 504 F.2d 441, 443 (10th Cir. 1974), cert. denied, 420 U.S. 934 (1975), where the court, citing Byers, held that a suspect's response to an FBI agent's questions asking him his height and weight "was not communicative in nature," because it "merely acknowledged the existence of physical characteristics" which were plainly observable.

79. See notes 54-55 supra and accompanying text; cf. State v. Smith, 295 Minn. 65, 69, 203 N.W.2d 348, 351 (1972). Even if the Byers approach-balancing the government's regulatory needs against the individual's privilege against self-incrimination-can be applied in a criminal context, it is clear that self-incriminating information should not be compelled from an individual when there is no legitimate regulatory need for the information. See text accompanying notes 69-75 supra.

80. Miranda v. Arizona, 384 U.S. 436, 460 (1966).

81. If the suspect has been previously arrested, the police could obtain the necessary information by simply looking in their own files. If, on the other hand, the suspect has no previous arrests, the data could be obtained from other public records (for example, from the Department of Motor Vehicles), by questioning his family and neighbors, or perhaps by searching his personal possessions. See note 101 infra.

82. Lefkowitz v. Turley, 414 U.S. 70 (1973); Couch v. United States, 409 U.S. 322, 327-28 (1973); Schmerber v. California, 384 U.S. 757, 760-61 (1966); Miranda v. Arizona, 384 U.S. 436, $442-43$ (1966).

83. See also People v. Hernandez, 263 Cal. App. 2d 242, 253-54, 69 Cal. Rptr. 448, 
irrelevant. The majority position was most convincingly stated in Hines, where the Second Circuit concluded that the only interrogation condemned in Miranda was investigative interrogation. ${ }^{84}$ No distinction was drawn in Miranda itself between investigative and noninvestigative interrogation..$^{85}$ The Hines court, however, reasoned that since the Miranda rules are intended to prevent police abuses in the form of third-degree interrogation tactics, ${ }^{86}$ and such abuses are only likely to occur when an officer is seeking incriminating evidence, there is no need for the Miranda safeguards when the purpose of the questioning is only to obtain adninistrative information.

This syllogism is valid, but it is based upon the false premise that the sole purpose of the Miranda warnings is to prevent police abuses. ${ }^{87}$ Another equally important purpose of the Miranda rules is to place the arrested individual on an equal footing with his interrogators by making him "acutely aware that he is faced with a phase of the adversary system," and by insuring that he is aware of the nature and extent of his constitutional rights throughout this adversary proceeding. ${ }^{88}$ Thus, as

454-55 (1968); People v. Walters, 252 Cal. App. 2d 336, 338-39, 60 Cal. Rptr. 374, 376 (1967); State v. Rassmussen, 92 Idaho 731, 736, 449 P.2d 837, 842 (1968); Clarke v. State, 3 Md. App. 447, 450-51, 240 A.2d 291, $293-94$ (1968); State v. Jordan, 506 S.W.2d 74, 83 (Mo. App. 1974).

84. 521 F.2d at 1112-13.

85. The Supreme Court defined custodial interrogation as "questioning initiated by law enforcement officers after a person has been taken into custody or otherwise deprived of his freedom of action in any significant way." Miranda v. Arizona, 384 U.S. 436, 444 (1966). Professor Kamisar, in discussing the problem of incriminating statements made during booking, has argued that "absent special circumstances" booking questions do not generate the same amount of pressure on the suspect which investigative questioning generates, and "therefore unresponsive incrimmating statements made in reply to such questions" should be admissible, even if the Miranda warnings have not been given. See Kamisar, "Custodial Interrogation" Within the Meaning of Miranda, in

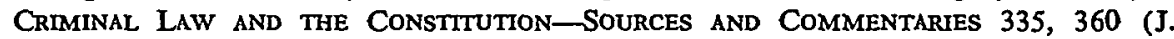
Israel \& Y. Kamisar eds. 1968) (emphasis added). The question of whether responsive incriminating statements made in reply to booking questions should be adinissible is left open. Using Kamisar's "pressure" analysis, it seems that the fact that the booking information requested is itself incriminating would cause a suspect to feel just as much pressure as he would in an ordinary investigative interrogation. Morrison, for example, must have felt a great deal of pressure when the police, after arresting hin for passing counterfeit money, required him to admit that he was on probation from a conviction for that same crime.

86. See Miranda v. Arizona, 384 U.S. 436, $455-57$ (1966); United States v. Stamp, 458 F.2d 759, 781 (D.C. Cir. 1971), cert. denied, 406 U.S. 975 (1972).

87. This conclusion is drawn from the language of Miranda itself. Language in several recent Supreme Court cases suggests, however, that this "false premise" may become the controlling view in the near future. See Michigan v. Mosley, 423 U.S. 96 (1975); United States v. Peltier, 422 U.S. 531 (1975); Michigan v. Tucker, 417 U.S. 433 (1974). See note 6 supra.

88. Miranda v. Arizona, 384 U.S. 436, 468-69 (1966). If incriminating information 
the Proctor court stated, Miranda would be violated if a suspect were under an impression that he must divulge incriminating information, even though no compulsion was intended by the booking officer. ${ }^{89}$

In most police imvestigation situations, the two purposes of Miran$d a$ coincide-the warnings will be necessary both to prevent police abuses and to insure that the suspect is aware of his rights. In the booking cases, however, only one of the dangers to which Miranda was directed will generally be present, leading to divergent results depending on which danger a court chooses to emphasize. There is little likelihood of any police abuses taking place during bookmg, but there is a strong possibility that a suspect may answer an incriminating booking question because he believes that he has no right to refuse to do so. The conflicting views of the applicability of Miranda to booking can be explained by the fact that the Farley, ${ }^{\circ 0} \mathrm{La}$ Monica, and Hines courts place primary emphasis on the policy of preventing police abuses, while the Proctor court implicitly empliasized the policy of insuring that the suspect is in a position to make an intelligent decision as to whether or not he desires to cooperate with the police.

The courts have encountered a parallel problem in determining whether or not an individual who has not been arrested is in "custody"01 and therefore entitled to the Miranda warnings. ${ }^{92}$ When an officer questions an individual before there has been a formal arrest, the officer may have no intention of depriving the individual of his freedom of action, and yet if the individual believes that the officer plans to hold him in custody he will feel the same compulsion that an arrested individual feels. A majority of the courts liave rejected the use of subjective

is requested during booking, then the adversary process has already begun. The police have an interest in learning of the incriminating information, but the best interests of the suspect require that he withhold it.

89. Proctor v. United States, 404 F.2d 819, 820-21 (D.C. Cir. 1968).

90. In Farley, the Court of Appeals for the Fifth Circuit did not employ the "lack of investigative intent" argument, but it did rely on the fact that there was no evidence of any overt acts of compulsion during the questioning. As do the analyses in LaMonica and Hines, the Fifth Circuit's reasoning in Farley fails to recognize that booking, like custodial investigative interrogation, is inherently coercive.

91. "Custodial interrogation" may take place even if the person interrogated is never arrested, since the definition given in Miranda includes all "questioning initiated by law enforcement officers after a person has been taken into custody or otherwise deprived of his freedom of action in any significant way." Miranda v. Arizona, 384 U.S. 436, 444 (1966) (emphasis added).

92. See 1 Practicing Law Institute, Criminal Procedure Sourcebook $173-76$ (1970); Kamisar, supra note 85, at 360-82; LaFave, "Street Encounters" and the Constitution: Terry, Sibron, Peters, and Beyond, 67 Mich. L. Rev. 39, 93-106 (1968); Smith, The Threshold Question in Applying Miranda: What Constitutes Custodial Interrogation?, 25 S.C.L. REv. 699, 706-14 (1974). 
tests which rely on either the officer's intent ${ }^{93}$ or the suspect's impressions $^{94}$ to determine whether the particular interrogation was "custodial" in nature. Instead, they have adopted a compromise objective test: whether, taking into account the observable actions of the police officer and the other circumstances of the questioning, a reasonable person would have concluded that he was deprived of his freedom of action. ${ }^{95}$

In order to give some effect to both of Miranda's purposes, courts should use a parallel objective test in their attempts to determine the apphicability of Miranda to the defendant's booking: whether a reasonable individual, arrested and booked under the same circumstances as the defendant, would have believed that he was required to answer the booking questions even if his answers might incriminate him. If so, then the defendant should be afforded Miranda protection. ${ }^{96}$

Since the circumstances under which a person is booked are fairly uniform, ${ }^{97}$ some general conclusions can be reached under this objective test. It is readily apparent from the actions of the suspects in cases discussed in this Note ${ }^{98}$ that a reasonable person is likely to believe that he must answer the booking questions. ${ }^{99}$ Apparently, booking is as

93. Smith, supra note 92, at 712; see United States v. Hall, 421 F.2d 540, 544 (2d Cir. 1969), cert. denied, 397 U.S. 990 (1970); Williams v. United States, 381 F.2d 20 (9th Cir. 1967).

94. [A]ny formulation making the need for Miranda warnings depend upon how each individual being questioned perceived his situation would require a prescience neither the police nor anyone else possesses. United States $\vee$. Hall, 421 F.2d 540, 544 (2d Cir. 1969), cert. denied, 397 U.S. 990 (1970).

95. See United States ex rel. Sanney v. Montanye, 500 F.2d 411, 416 (2d Cir.), cert. denied, 419 U.S. 1027 (1974); United States v. Irion, 482 F.2d 1240, 1244 (9th Cir.), cert. denied, 414 U.S. 1026 (1973); Iverson v. North Dakota, 480 F.2d 414, 422 (8th Cir.), cert. denied, 414 U.S. 1044 (1973); United States v. Bekowies, 432 F.2d 8, 12 (9th Cir. 1970); United States v. Hall, 421 F.2d 540, 543-45 (2d Cir. 1969), cert. denied, 397 U.S. 990 (1970); Freije v. United States, 408 F.2d 100, 103 (1st Cir.), cert. denied, 396 U.S. 859 (1969); Lowe v. United States, 407 F.2d 1391, 1397 (9th Cir. 1969); People v. Arnold, 66 Cal. 2d 438, 447-49, 426 P.2d 515, 521-22, 58 Cal. Rptr. 115, 121-23 (1967); People v. Parada, - Colo. -, 533 P.2d 1121 (1975).

96. The proposed test follows the Miranda approach, in that it avoids the necessity of an ad hoc examination of the circumstances surrounding each particular investigation by providing a rule of general applicability. Compare, for example, the difficulty of reaching consistent results under the Hines test, which focuses on the investigative intent of the officer, see notes 34-43 supra and accompanying text, or the Proctor analysis, which predicates the applicability of Miranda on the subjective impressions of the suspect, see notes 20-24 supra and accompanying text.

97. See note 2 supra.

98. See cases cited in note 4 supra.

99. In one empirical study, it was found that, even after having received the Miranda warnings, sixty-seven percent of the arrested individuals questioned belicved that they had to answer identification questions put to them by the police. Of the 
inherently coercive a situation as custodial investigative interrogation. For this reason, in the ordinary case the police should be allowed to ask a suspect for his name and address before they give the Miranda warnings; however, before they ask any other booking questions, they should be required to warn the suspect of his rights, and if the suspect desires to remain silent or to speak with an attorney, all questioningboth booking and investigative-should cease.

\section{The Public Knowledge Argument}

The thrust of the public knowledge argument advanced in Farley and Morrison to justify exempting booking from Miranda is that it is meaningless to worry about whether the suspect felt compelled to give his address or other identification information to the police since such information is readily available in a telephone book or some public file. Even if he had given the information because of some compulsion inherent in the booking process, these courts have reasoned, the disclosure could not have had any effect on the outcome of the case, because the police would undoubtedly have obtained the information before trial anyway. ${ }^{100}$ The public knowledge argument would apply to any information which is readily available through soine means other than interrogation, such as the examination of public documents, the search of the suspect's personal possessions, ${ }^{101}$ or the use of nontestimonial identifica-

sixty-seven percent, seven percent believed that they were required to identify not only themselves, but also any physical objects with which they were confronted. Another seven percent believed that they were required to answer any questions asked of them. See Leiken, Police Interrogation in Colorado: The Implementation of Miranda, 47 DENVER L.J. 1, 16 (1970).

100. See Morrison v. United States, 491 F.2d 344, 346-47 (8th Cir. 1974); Farley v. United States, 381 F.2d 357, 359 (5th Cir.), cert. denied, 389 U.S. 942 (1967). See also State v. Jordan, S06 S.W.2d 74, 83 (Mo. App. 1974).

The public knowledge argument is logically related to the harmless error rule as applied in Hines, see note 43 supra. In each instance, the conclusion reached is that the lack of practical impact outweighs the presence of a technical constitutional error.

101. As part of the booking process, the police seize and inventory the personal effects of those suspects who will be incarcerated. This "established and routine" part of the booking process has been held to be consistent with the fourth amendment, United States v. Edwards, 415 U.S. 800,803 \& nn.4-6 (1974), because of the administrative need to prevent weapons or other contraband from being introduced into the prison, and the need to protect the suspect's possessions. If incriminating evidence is discovered by this inventory search, it may be admitted in evidence. Id. at 803 \& nn.4-5 (citing cases).

While it is clear that the police may seize any papers and documents which are in the suspect's possession when he is arrested, the question of whether such testimonial items can be used as incriminating evidence against him remains unresolved. When the Supreme Court held that items which were merely evidentiary in nature (as opposed to 
tion procedures. ${ }^{102}$

Although initially appealing, the public knowledge argument has major weaknesses. First, even if the argument were theoretically sound, it would not justify a broad exemption of all booking questions froin Miranda. Some of the information requested during booking (such as a suspect's aliases, occupation, and explanations about his personal possessions) may not be discoverable from public records or through ordinary police investigation. Before any such nonpublic data is asked for, a suspect would have to be warned that he lias a right not to answer.

Second, the fact that an item of information is readily available through independent investigation is really a very persuasive reason to require the police to obtain it there, rather than from a suspect who has already indicated that he does not want to be questioned. Such a rule would not have any harmful effects on the government's case, and would better implement the plilosophy of the fifth amendment, which is to preserve an adversary system of criminal procedure by preventing the government from compelling self-incriminatory disclosures so that it

\footnotetext{
items which were the instrumentalities or fruits of crimes) could be lawfully seized, it noted that:

The items ... involved in this case are not "testimonial" or "communicative" in nature, and their introduction therefore did not compel respondent to become a witness against himself in violation of the Fifth Amendment. . . This case thus does not require that we consider whether there are items of evidential value whose very nature precludes them from being the object of a reasonable search and seizure. Warden v. Hayden, 387 U.S. 294, 302-03 (1967).
}

The Court has not considered the issue since Hayden, but a majority of the circuit courts have held that personal papers and documents are admissible as incriminating evidence against the suspect from whom they were seized, on the ground that the compulsion involved in a search and seizure is not a compulsion requiring the defendant to perform a testimonial act. See, e.g., Shaffer v. Wilson, 523 F.2d 175, 177-79 (10th Cir. 1975), cert. denied, 44 U.S.L.W. 3756 (June 30, 1976); United States v. Dawson, 516 F.2d 796, 806-07 (9th Cir.), cert. denied, 423 U.S. 855 (1975); United States v. Murray, 492 F.2d 178, 191 (9th Cir. 1973), cert. denied, 419 U.S. 854 (1974); United States v. Bennett, 409 F.2d 888, 896-97 (2d Cir. 1969), cert. denied, 402 U.S. 984 (1971). Contra, Hill v. Philpott, 445 F.2d 144 (7th Cir.), cert. denied, 404 U.S. 991 (1971). Some writers have suggested that the admissibility of such documentary evidence should depend on its public or private nature. See, e.g., Comment, Papers, Privacy and the Fourth and Fifth Amendments: A Constitutional A nalysis, 69 Nw. U.L. REv. 626, 647-48 (1974); Comment, The Search and Seizure of Private Papers: Fourth and Fifth Amendment Considerations, 6 Loyola UNiv. L. Rev. 274, 300-04 (1973). This approach also has been adopted in MOdel CODE of Pre-ArRaignment Procedure $\S 210.3(2)(1975)$, which would prohibit the use of "personal diaries, letters, or other writings or recordings, made solely for private use or communication to an individual occupying a family, personal or other confidential relation, other than a relation in criminal enterprise . . . Even under this more limited approach, the police can still obtain a substantial amount of information from such non-private documents as the suspect's driver's license, draft card, social security card, and credit cards.

102. See notes 56-64 supra and accompanying text. 
might "avoid the burdens of independent investigation."103 Applying the Miranda exclusionary rule to routine identification questions would deter police officers from using the shortcut of interrogation to obtain evidence which could be found independently. ${ }^{104}$

\section{CONCLUSION}

It has been demonstrated that the arguments for exempting the entire booking process from the Miranda safeguards are not wholly persuasive. Most of the information requested during booking is testimonial, and much of it is potentially incriminating. Furthermore, it is apparent that a substantial proportion of all arrested individuals believe that they are required to answer police identification questions, even if the solicited information tends to incriminate then. The only way to give adequate protection to the privilege against self-incrimination is to insure that the suspect is warned of his right not to answer those booking questions which call for nonessential, constitutionally-protected data.

103. Garner v. United States, 96 S. Ct. 1178, 1183 (1976); accord, Miranda v. Arizona, 384 U.S. 436, 460 (1966).

104. [T] he exclusionary rule, designed to discourage illegal police activity, is useless if the police may ... illegally seize evidence and then claim "we would have obtained it anyway." Pitler, "The Fruit of the Poisonous Tree" Revisited and Shepardized, 56 CALIF. L. REv. 579, 630 (1968).

Some courts have adopted the so-called "inevitable discovery" exception to the fruit of the poison tree doctrine, which is similar to the public knowledge argument. These courts would allow the fruit of illegally obtained evidence to be used against a defendant if it appears that such evidence would have been discovered eventually even without the use of the original illegally seized evidence. See, e.g., United States v. Nagelberg, 434 F.2d 585 (2d Cir. 1970), cert. denied, 401 U.S. 939 (1971); Killough v. United States, 336 F.2d 929 (D.C. Cir. 1964); People v. Soto, 55 Misc. 2d 219, 285 N.Y.S.2d 166 (App. Div. 1967), appeal dismissed, 27 N.Y.2d 735, 262 N.E.2d 682, 314 N.Y.S.2d 544 (1970). However, the illegally obtained evidence itself is still inadmissible. See Gilbert v. California, 388 U.S. 263 (1967) (Court held inadmissible certain illegally obtained lineup identifications, even though the same witnesses could undoubtedly have identified the defendant in court under proper circumstances).

The "inevitable discovery" rule has been criticized by the courts and commentators on the same grounds expressed in the text accompanying this note and note 103 supra. See, e.g., United States v. Paroutian, 299 F.2d 486, 489 (2d Cir. 1962); Bynum v. United States, 262 F.2d 465, 467-69 (D.C. Cir. 1958) (court reversed a conviction which had been based partially on fingerprint evidence because the fingerprints used at trial had been taken pursuant to an illegal arrest, even though another set of the defendant's fingerprints were available from the FBI. At a second trial, the FBI prints were used, the defendant was convicted once again, and this time the conviction was affirmed. Bynum v. United States, 274 F.2d 767 (D.C. Cir. 1960), cert. denied, 379 U.S. 908 (1964)); People v. Sesslin, 68 Cal. 2d 418, 439 P.2d 321, 67 Cal. Rptr. 409 (1968), cert. denied, 393 U.S. 1080 (1969) (handwriting exemplar held inadmissible because taken during an illegal arrest). See also Davis v. Mississippi, 394 U.S. 721 (1969) (fingerprints taken pursuant to illegal arrest held inadmissible). 
Some minimal identification information is, however, not only essential for the maintenance of police arrest records, but also outside the scope of the fifth amendment privilege. Accordingly, an arresting officer should be permitted to compel a suspect to reveal his name and address before the Miranda warnings have been given. The Miranda exemption, however, should be limited to this data alone. The officer should not be permitted to ask additional booking questions unless the Miranda procedures have been followed and the suspect has executed a valid waiver of his rights to remain silent and to have counsel present. Such a rule would achieve the inost reasonable balance between the rights of the individual and the legitimate interests of law enforcement authorities. The suspect's fifth amendment privilege would be left inviolate, while the authorities could obtain the desired information in the form of nontestimonial evidence, froin public records, or through independent investigation. 